\title{
Environmental Safety Assessment of Fertilizer Products
}

\author{
Piotr Zawadzki*, Marcin Głodniok \\ Central Mining Institute, Department of Water Protection, Katowice, Poland
}

Received: 9 March 2020

Accepted: 14 April 2020

\begin{abstract}
The danger posed by sewage sludges, although subjected to various treatment processes, contributes to the fact that fertilizers introduced into the soil pose a sanitary and ecological threat. Minimizing the risk of using fertilizers produced from sewage sludges is possible due to legal regulations, the most important of which are the Act of 26 July 2000 on fertilizers and fertilization and numerous regulations of the Minister of Agriculture and Rural Development. Due to the fact that some parameters such as pharmaceutical substances have not been included in legal regulations, comprehensive researches on the impact of fertilizers produced from sewage sludges are justified, in particular with regard to soil, ground and water environment and also on the quality of crops. Taking into account the current legal regulations and the diverse composition of sewage sludges, full safety analysis including both biological analyses and risk assessment is necessary to perform. As part of this work, the possibilities of environmental safety assessment of fertilizer products based on stabilized municipal sewage sludges are presented. This article presents the most popular methods of sewage sludge safety analysis in the following environment: leachate, ground and surface waters, soil and plants.
\end{abstract}

Keywords: municipal sewage sludges, fertilizers, safety analysis, risk assessment, environmental management

\section{Introduction}

Despite the obligation of disposal, sewage sludges are still a waste, not a product that they can become after the application of appropriate treatment technologies. The possibility of using sewage sludge as a fertilizer depends on the content of organic matter and nutrients (carbon, nitrogen, and phosphorus), the presence of hazardous substances as well as biological hazards and the technology of their treatment. A properly prepared

*e-mail: pzawadzki@gig.eu sludge is a valuable source of nutrients for crops (phosphorus and nitrogen), as well as a rich source of macroelements and microelements. The use of sewage sludges as a substrate for the production of innovative fertilizer products can be regarded as an alternative way to improve soil fertility and a supporting effect of mineral fertilization. The use of sewage sludges contributes to the increase of biological activity and soil structure as well as the growth of crops. Mineral fertilizer characteristics will allow its use for agriculture in the cultivation of all plants. The fertilizer product can be used to set up squares, lawns and green areas as well as for the recultivation of industrial soils. Therefore, they can be used as organic or organic- 
mineral fertilizers, if they meet the requirements of The Act of Fertilizers and Fertilization [1]. Numerous studies have shown that sewage sludges can also be a source of priority substances and priority hazardous substances in the field of water policy, i.e. substances that are listed in Annex $\mathrm{X}$ of the Water Framework Directive [2-5]. Due to the fact that the fertilizer is used in the cultivation of food plants, it is important to analyse its potential impact on human health. For this reason, the environmental safety analysis should also be carried out in the context of substances included in the Watch List under the Water Framework Directive, such as 17- $\alpha$-ethinylestradiol, 17- $\beta$-estradiol, estrone, as well as some certain unmonitored substances, e.g. diclofenac and ibuprofen [6].

\section{Legal Aspects}

Under the Polish Act on Waste - the superior legal act regulating waste management in Poland - the term municipal sewage sludges means "coming from the treatment plants sludge from the anaerobic digesters and from other installations for the treatment of municipal wastewater, and other wastewater with a composition similar to the composition of municipal wastewater" [7]. According to article 96 paragraph 4 of the Act on Waste "the use of municipal sewage sludges is possible if they are stabilized and prepared properly according to the purpose and method of their use, in particular by subjecting them to biological, chemical or thermal treatment, or another process that reduces the susceptibility of municipal sewage sludge to putrification and eliminates the risk for environment or human life and health". In addition, according to the Regulation of the Minister of the Environment on municipal sewage sludges [8], the municipal sewage sludge may be used on the grounds under the conditions specified according to the article 96 paragraph 13 of the Act of on Waste. These conditions relate, i.e. to the doses of sludges; scope, frequency and reference methods for testing municipal sewage sludges and grounds on which these sludges are to be used; the content of heavy metals in these sludges and ground; the content of pathogenic bacteria (Salmonella) and eggs of intestinal parasites (Ascaris sp., Trichuris sp., Toxocara $\mathrm{sp}$.).

The chemical composition of municipal sewage sludges depends largely on the type of treated wastewater and the method of its treatment. They are characterized by high moisture content, a significant participation of organic substances, as well as high potential for putrefaction. The use of municipal sludges in agriculture as fertilizers poses a huge risk of microbial and parasitological pollution of soil, ground and surface waters, as well as cultivated plants [9]. The content of metals is particularly important, which often limit the agricultural, ground remediation, etc. use of sludges. For living organisms, especially dangerous are metals which density exceeds $4.5 \mathrm{~g} / \mathrm{cm}^{3}$ - called heavy metals [10]. The most dangerous forms in which heavy metals occur are their dissolved forms, co-precipitated with metal oxides and as adsorbed or associated with biological residues [11]. The main harmful heavy metals include cadmium, lead, arsenic, and mercury. Microbiological contaminants should also be considered, including threats related to the presence of bacteria, viruses, fungi and invasive forms of parasites, mainly intestinal. Some sewage sludge may contain increased amounts of toxic organic compounds, i.e. pesticides, chloroform, phenols, aromatic hydrocarbons (BTX), aliphatic hydrocarbons, polycyclic aromatic hydrocarbons (PAHs), polychlorinated biphenyls (PCBs), polychlorinated dibenzodioxins (PCDDs), polychlorinated dibenzofurans (PCDFs) [12].

Increasing environmental pollution causes that more and more compounds are added to the list of priority substances and priority hazardous substances in the context of the Directive 2000/60/EC of the European Parliament and Council of 23 October 2000 establishing a framework for the Community action in the field of water policy [5]. The term "priority substance" is introduced by the Directive 2000/60/EC, while the definition of these substances is introduced into Polish law by the Water Law Act [13]. Under this Act, priority substances mean "the substances that are chemical pollutants of surface water and present a risk that may cause, in particular, acute and chronic toxicity to aquatic organisms, accumulation of pollutants in the ecosystem, and loss of habitats and biodiversity, as well as threats to human health, and which emissions to waters should be gradually reduced". In turn, priority hazardous substances are "the substances or groups of substances that are toxic, persistent and susceptible to bioaccumulation, as well as other substances or groups of substances which level reaches a level of concern, which should be gradually removed from the aquatic environment in order to eliminate them".

An important change in the number of priority substances took place in 2013. A European priority list of 33 substances extended to 45 by the Directive 2013/39/EU of the European Parliament and of the Council of 12 August 2013 amending Directives 2000/60/EC and 2008/105/EC as regards priority substances in the field of water policy [14]. The updated list of priority substances mainly includes aromatic hydrocarbons, metals with a density above $4.5 \mathrm{~g} / \mathrm{cm}^{3}$ and their compounds, as well as the substances contained in pesticides, halogen derivative, and organophosphorus compounds. The European Commission also established a watch list of substances for which Union-wide monitoring data are to be gathered for the purpose of supporting future prioritization [15]. According to the Decision 2018/840 of 5 June 2018, the watch list contains six substances and two groups of substances for which there is an obligation to monitor them in the aquatic environment. Among the substances on the 
watch list there are 17- $\alpha$-ethinylestradiol, 17- $\beta$-estradiol, and macrolide antibiotics, including erythromycin, clarithromycin, and azithromycin [6].

\section{Safety of Sewage Sludge Usage}

It is justified to conduct comprehensive studies, taking into account parameters not included in legal regulations, on the effectiveness of the sewage sludges use and their impact on soils, ground and water environment, and the quality of crops. The assessment of the impact of sewage sludges on the environment (soil, ground, and water) and plant quality should be carried out on a full technical scale at many national facilities. The obtained test results will allow to verify and clarify the adopted environmental impact assumptions. The obtained results will also allow for technology development in the context of improving the environmental safety of the product, and depending on the results the corrective actions will be introduced in the method of producing fertilizers. The safety of using sewage sludges as fertilizer products should be determined on the base of at least two methods of analysis - biological, which is based on the use of living organisms, and physical, based on the risk analysis.

\section{Biological Analysis}

The human presence in the environment determines that substances posing a threat to human health and life are introduced into all ecosystems. These substances, often occurring at low concentration levels $\left(\mathrm{ng} / \mathrm{dm}^{3}, \mu \mathrm{g} / \mathrm{dm}^{3}\right)$, exhibit both toxic effects that occur after a short exposure time, and are also considered in terms of long-term health effects, such as possible carcinogenic, teratogenic and embryotoxic effects, as well as disrupting the functioning of the reproductive system [16].

The biological analysis is used to study and assess the adverse or harmful effects of chemical substances and other factors on organisms, and also analyses the probability of their occurrence in different exposure conditions. Bioassays provide comprehensive information on the scale of toxicity to a greater extent than chemical analyses. The use of biological analysis to assess the effects of various substances on living organisms allows, i.e. identification of properties such as toxicity, mutagenicity, carcinogenicity, teratogenicity, and allergenicity [17].

The motive for including biological analysis in the control of the safety of municipal-sewage-sludges based fertilizers is the possibility of conducting studies in two basic directions. In the first direction, it is possible to analyse the impact of pollutants on biological material. In the second one, biomonitoring of the environment.
It is a measure of the response of living organisms to the changes occurring in the environment [17]. The assessment of the effects of chemical substances on organisms should take into account different sensitivity to toxic substances in groups of organisms and between species, and even in different strains of the same species. The regular, temporal and spatial observation of living organisms is also important, because only this way it is possible to determine the state of the ecological system and the biotic and abiotic parameters of its components, including substances and anthropogenic interactions. Many laboratory methods have been developed to determine the relationships and effects of toxic compounds on living organisms, and methods for rapid determination of toxicity or the presence in the environment of substances of significant importance for the biological activity of organisms $[18,19]$. The use of living organisms for the biological analysis together with the determination methods are listed in Table 1 - Table 3. The toxicity of chemical compounds to aquatic organisms can be determined by using standard methods covering many species of freshwater and saltwater organisms: microorganisms, algae, invertebrates, and fish inhabiting aquatic environments and bottom sediments [20-25]. The toxicity of soil contaminants can be tested using soil microorganisms, plants, oligochaetes including earthworms, soil arthropods and other organisms [26]. Measurements of the life activity of soil microorganisms are a sensitive indicator of chemical stress caused by pollutants. Standard tests using soil microflora measure such parameters as breathing [27, 28], nitrification processes, transformations of nitrogen compounds [29, 30], [31], transformations of carbon compounds [32], the amount of biomass [33, 34], dehydrogenase activity of soil microorganisms $[35,36]$. Seed plants are used mainly in soil ecotoxicological studies. Commonly used organisms include rice, oats, wheat, ryegrass, rapeseed, lettuce, red clover, and watercress [37,38]. Invertebrates are also used in ecotoxicological studies. Test organisms are, among others, nematodes (e.g. Caneorhabditis elegant), earthworms (e.g. Eisenia fetida, Enchytraens albinus, E. cypricus), springtails (e.g. Folsomia candida) or mites (e.g. Hypoaspis aculeifer) [37, 39-44]. Sewage sludges are a habitat for numerous microorganisms (autochthonous, allochthonous, multicellular organisms and various species of fungi), therefore the presence in the sludge of coliforms, anaerobic sporulating bacteria Clostridium perfringens, bacteria of Salmonella sp. genus, quantity and viability of Ascaris sp., Trichuris sp. and Toxocara sp. eggs is determined. In Polish regulation of the Minister of the Environment on municipal sewage sludges [8], the basic parameters of sanitary assessment of sewage sludge for agricultural sector are bacteria of Salmonella sp. Genus [45] and gastrointestinal parasite eggs, representatives of parasitic fauna of Ascaris sp., Trichuris sp. and Toxocara sp. [46-48]. 
Table 1. List of selected types of tests carried out on soil microorganisms in biological analysis.

\begin{tabular}{|c|c|c|c|}
\hline Short description & References & Short description & References \\
\hline $\begin{array}{c}\text { Determination of the live activity of metabolically } \\
\text { aerobic heterotrophic biomass of microorganisms in the } \\
\text { soil }\end{array}$ & {$[27]$} & $\begin{array}{c}\text { Determination of potential nitrification and } \\
\text { inhibition of nitrification }\end{array}$ & {$[31]$} \\
\hline $\begin{array}{c}\text { Sampling, handling and storage of soil samples } \\
\text { intended for testing aerobic microbiological } \\
\text { processes in laboratory conditions }\end{array}$ & {$[28]$} & $\begin{array}{c}\text { Indication of potential effects of chemicals on } \\
\text { the activity of carbon metabolism by soil } \\
\text { microorganisms }\end{array}$ & {$[32]$} \\
\hline $\begin{array}{c}\text { Determination of nitrogen mineralization and nitrifica- } \\
\text { tion in soils and the impact of chemical substances on } \\
\text { these processes }\end{array}$ & {$[29]$} & $\begin{array}{c}\text { Determination of the amount of biomass of } \\
\text { microorganisms in soil by the induction of the } \\
\text { breathing method by adding a substrate }\end{array}$ & {$[33]$} \\
\hline $\begin{array}{c}\text { Testing of long-term effects of chemicals, after } \\
\text { one-time exposure, on nitrogen transformation activity } \\
\text { by soil microorganisms }\end{array}$ & {$[30]$} & $\begin{array}{c}\text { Determination of the amount of biomass of } \\
\text { microorganisms in soil by measuring the total } \\
\text { extracted organic biomass material }\end{array}$ & {$[34]$} \\
\hline
\end{tabular}

Table 2. List of selected types of tests carried out on plants in biological analysis.

\begin{tabular}{|c|c|c|}
\hline Test organism & Short description & Literature \\
\hline $\begin{array}{c}\text { Onion, corn, rape, cucumber, } \\
\text { soybean, sunflower, tomato, chickweed }\end{array}$ & $\begin{array}{c}\text { Testing of the influence of chemical substances on the processes of } \\
\text { germination and growth of seedlings is carried out using the OECD standard } \\
\text { method }\end{array}$ & [49] \\
\hline Barley & $\begin{array}{c}\text { Method for assessing root growth inhibition by comparing plant root growth } \\
\text { rate under standard conditions on the control soil and potentially polluted soil }\end{array}$ & [50] \\
\hline $\begin{array}{c}\text { Rye, rice, oats, wheat, clover, } \\
\text { watercress }\end{array}$ & $\begin{array}{c}\text { Soil quality assessment by testing the potential impact of chemical compounds } \\
\text { on the emergence and growth of higher plants }\end{array}$ & {$[51]$} \\
\hline $\begin{array}{c}\text { Phytotoxkit }{ }^{\mathrm{TM}} \text { (sorghum, seed pepper, } \\
\text { white mustard) }\end{array}$ & $\begin{array}{c}\text { Digital image registration after three days of germination of seeds placed in the } \\
\text { test and control soil and quantitative comparison of the germinated seeds, and } \\
\text { determination of root length }\end{array}$ & [52] \\
\hline
\end{tabular}

Table 3. List of selected types of tests carried out on pedofauna in biological analysis.

\begin{tabular}{|c|c|c|}
\hline Test organism & Short description & Literature \\
\hline California earthworms & Identification of potentially toxic chemical substances for earthworms & {$[39]$} \\
\hline $\begin{array}{c}\text { Nematodes (e.g. Caenorhabditis } \\
\text { elegans) }\end{array}$ & $\begin{array}{c}\text { Assessment of lethal or sub-lethal toxic effects on nematodes in short-term tests } \\
\text { in terrestrial ecosystems }\end{array}$ & [42] \\
\hline Springtails (e.g. Folsomia candida) & Assessment of the effect of pollutants on the reproduction of springtails in soil & {$[43]$} \\
\hline $\begin{array}{c}\text { Mites (e.g. Hypoaspis aculeifer) } \\
\text { performance of soil mite species }\end{array}$ & $\begin{array}{c}\text { Assessment of the effect of chemical substances in soil on the reproductive } \\
\text { [44] }\end{array}$ \\
\hline
\end{tabular}

\section{Toxicity Tests}

The base of toxicological studies is the doseresponse relationship, i.e. the relationship between the dose of a given toxic substance and the probability of occurrence of a specific biological effect in the indicator organisms. In the studies, laboratory toxicological tests are used. The term "toxicity" is defined as the feature of chemical compounds causing dysfunction in the body into which these substances have entered. A distinction is made between acute and chronic toxicity.

\section{Acute Toxicity Tests}

The acute toxicity (chronic) is defined as adverse effects (consequences) caused in the organism, occurring shortly after oral administration or through the skin contact $[53,54]$. The acute toxicity tests were developed to assess the negative effects of a chemical substance at various concentrations on the selected organisms during exposure lasting up to 96 hours. The acute toxicity tests enable collecting information concerning the effects on organisms of the chemical compounds, mixtures of substances, wastewater, leachate, and waters intended for human consumption.

The laboratory animals, most commonly used for acute toxicity tests, are rats, mice, and dogs. It is recommended to perform tests on groups of animals of both sexes [55]. The most often performed acute toxicity test is the determination of median lethal dose $\mathrm{LD}_{50}$ and median lethal concentration $\mathrm{LC}_{50}$. The $\mathrm{LD}_{50}$ is usually expressed as the dose of the substance which, 
when administered once, causes the death of $50 \%$ of the studied animal population. The term $\mathrm{LC}_{50}$ refers to the specific concentration (e.g. in water or soil) that produces an analogous effect.

\section{Chronic Toxicity Tests}

The chronic toxicity is expressed as harmful changes occurring in the tested organisms, caused by prolonged exposure and after repeated or constant exposure to a chemical compound. The chronic toxicity tests include the assessment of adverse effects of factors, organic and inorganic compounds on individuals and populations under conditions of prolonged exposure to sub-lethal concentrations or doses. Lower than lethal doses of the substance are used. Then, the changes in physiological activity, e.g. digestive, reproductive, genetic and organ dysfunction are observed. In tests of this type, the organisms are exposed to the substance during the entire life cycle, beginning from the embryonic and adolescent phases, to the mature ones. The tests covering an incomplete life cycle include only a few of the most sensitive periods of life (reproduction, growth), but usually without its early stages [37]. The duration of experiments differs depending on the selected species, from approximately 21 days for crustaceans, e.g. daphnia (Daphnia magna), up to 275-300 days for fish, e.g. freshwater Pimephales promelas. Based on the results obtained during the tests, it is possible to determine the maximum tolerated concentration of the toxic substance (MATC), the highest concentration for which there is no significant increase in the severity of negative effects (NOEC - No Observed Effect Concentration), and the lowest concentration for which the severity of harmful effects is observed (LOEC Lowest Observed Effect Concentration).

\section{Toxicological Tests}

The toxicity assessment can be based on commercial toxicological biotests such as MICROTOX® (bacteria Aliivibrio fischeri), DAPHTOXKIT® (shellfish Daphnia magna) or ARTOXKIT M ${ }^{\circledR}$ (shellfish Artemia salina). The toxicity tests are also carried out using freshwater fish Danio rerio (ISO 15088:2007) and Lemna sp. (Growth Inhibition Test). The in-vitro tests called YES (Yeast Estrogen Screen) and YAS (Yeast Androgen Screen), using Saccharomyces cerevisiae yeast strains, turn out to be useful for assessing estrogenic or androgenic activity [56].

\section{Risk Assessment}

The use of sewage sludge as fertilizer implies the potential spread of a wide range of pollutants on agricultural soils. These pollutants can further migrate to various elements of the environment such as air, surface waters, and groundwaters. The pollutants can be adsorbed by plant roots or be absorbed and then used for production, e.g. for the animal feed. In turn, this may lead to the exposure of human and animals population. The risk assessment should include both the assessment after a single application into the soil and the assessment of the accumulation potential of pollutants after repeated use of the sewage sludges. The risk assessment should cover the environmental and health hazards that the sewage sludge may pose when used as fertilizer for cultivated soils.

The methodology for assessing the environmental risk of municipal-sewage-sludge based fertilizes can be applied on the base of the risk assessment principles, set out by the US Environmental Protection Agency [57] and French and Norwegian experience [58, 59]. As part of the established methodology, the analysis of environmental risk is carried out according to the steps shown in Fig. 1. The environmental risk associated with the use of fertilizers based on the stabilized sewage sludges can be assessed by determining the characteristics of the site, assessing the toxic effects for selected substances, and determining the routes of exposure.

\section{Characteristic Features of the Place}

The proposed method of risk analysis performance is based on the site-specific approach, referring to the specific characteristics of the given place. The risk assessment should first consider the terrain characteristics and the possibility of spreading pollutants, which will allow an accurate risk assessment at a later stage. The features which should be taken into account include: the qualitative and quantitative composition of sewage sludges (e.g. type of pollutants and their concentration), soil characteristics (soil texture, $\mathrm{pH}$, etc.), agricultural practices (use of sludges, fertilizers, type of crops). Déléry et al. (2006) [58] found that each substance listed in the legislation should be analysed in terms of potential risk of its spreading after the sewage sludges application.

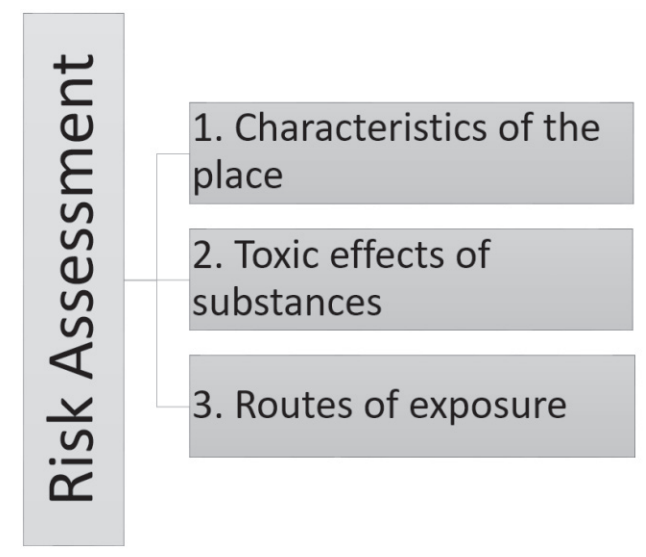

Fig. 1. Operation diagram for environmental risk analysis. Own study. 


\section{Routes of Exposure}

The purpose of this stage is to assess the dose of exposure (ED) to pollutants for each recipient (plants, animals, humans) and for each source of exposure (food, water, soil). This requires an estimation of the concentration of pollutants in the soil, where the sewage sludges are used (source of contaminants), the parameters needed to estimate the level of migration of pollutants into the human body, and the values of the parameters for daily food consumption. The routes of pharmaceuticals migration to the environment are shown in Figure 2. The pharmaceutical substances are characterized by high susceptibility to migration in the environment, and thus they are bioaccumulative and transfer in the food chain. They are also relatively resistant to degradation. The emission of the pharmaceuticals to the environment is caused by their excessive consumption and results from industrial activity. The direct sources of the pharmaceuticals are chemical plants, including production of pharmaceuticals, as well as the households. The pharmaceutical substances are identified primarily in the surface waters but they are increasingly present in groundwater, as well as in the sewage sludges [60]. They are released into the aquatic ecosystems mainly along with treated and poorly treated industrial and domestic wastewater, as well as through surface runoff, e.g. from the poorly secured landfills.

The concentration of each substance should be calculated theoretically, taking into account the amount of sludge spread in a given volume of soil, which in turn depends on the regulations, soil density and the depth of introduction of the sewage sludges. To estimate the total daily intake of pollutants resulting from the use of sewage sludge, exposure from all possible routes of exposure should be considered.

\section{Plants}

The uptake of pollutants by plants is important due to the potential for humans and animals exposure to these substances. Depending on the physico-chemical properties of the soil, only a part of the pollutants present in the soil is available for the plant root system (bioavailable fraction), which is the main route through which the pollutants are absorbed by plants. Gases pollutants can also be absorbed by the above-ground shoots and through the direct contact between soil and plant tissues. Translocation of pollutants, i.e. the transfer of pollutants from the roots to the above-ground parts of plants, and then to the leaves and grains is particularly important for migration of pollutions from a plant to animals and humans [59].

\section{Animals}

The pollutants introduced into the soil together with sewage sludges are easily accessible to soil organisms. The sorption of chemicals, and thus their bioavailability and toxicity to soil organisms, may depend on the soil characteristics. This means that the results of the test carried out on different soil types should not be compared, but should be normalized to standard conditions. The exposure of organisms living in the soil to pollutants present in sewage sludge results from

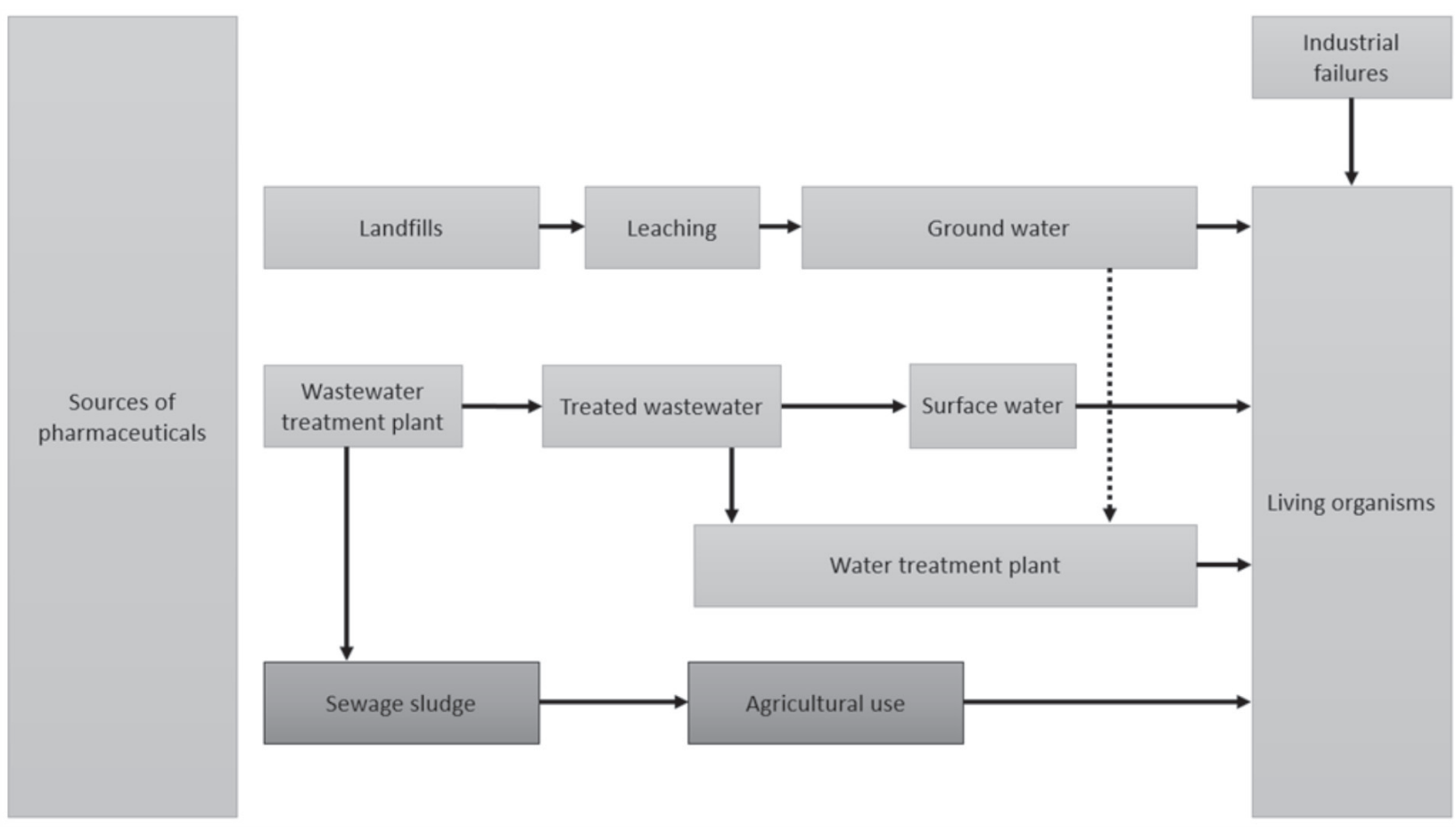

Fig. 2. Migration of pharmaceutical substances in the environment. Own study. 
contact with the sewage sludge (through the solid phase) or through the soil solution. The aquatic organisms living near the areas where the sewage sludges are used may be exposed to pollutants due to the soil erosion or surface runoff from the agricultural areas. After reaching the aquatic environment, pollutants spread between the liquid phase, suspended sediments and bottom sediments. The important route of exposure is the aqueous phase and the pollutants dissolved in it, however, the pollutants adsorbed on solid particles may also make an important route of exposure. In the case of herbivorous farmed animals such as cattle, sheep, and goats, the essential route of exposure to pollutants is feeding with grazing plants, grown in the areas fertilized with the sewage sludges. In this case, the time of keeping animals outdoors is crucial. In addition, the animals may consume the ground, and this consumption depends on the quality of the pasture and the mineral needs of the animals. It is usually up to several percent of the dry matter of the food ration [59].

\section{Humans}

The common ways of exposing humans to pollutants present in the sewage sludges are:

- plant products - exposure is due to the consumption of plants grown in soils where the sewage sludges were used; this route of exposure occurs only when the pollutants are absorbed by the plant roots; in the case of plants for which the aboveground parts are consumed, it is necessary to take into account the migration of pollutants from the root part to the aboveground part; human exposure to pollutants absorbed with plants can be estimated, e.g. based on consumption data gathered by [61],

- animal products - humans may be exposed to pollutants contained in the sewage sludges resulting from consumption of animal products, coming from the animals grazed on soil fertilized with the sewage sludges or fed with the fodder in such areas; the pollutants may accumulate in meat, eggs or milk, while on the other hand they are quickly metabolized and excreted in feces or urine,

- drinking water - the pollutants contained in the sewage sludges may migrate with leachate to surface waters and from there to the sources of drinking water; humans may be exposed to pollutants due to the presence of compounds dissolved in water or adsorbed on solid particles; the estimated daily consumption of water is assumed as 2 litres per day,

- accidental ingestion of soil by humans - children may eat soil particles in the playgrounds; the daily soil consumption among children was estimated at the level of $<0.2 \mathrm{~g}$ soil [62]; the highest concentrations of pollutants, that can be taken along with the consumed soil, occur in home gardens where fertilizers based on the sewage sludges are applied.

\section{Prediction of Pollutants Concentration in the Environment}

The purpose of the environmental safety assessment of the fertilizer products is to determine the predicted environmental concentrations $(P E C-$ Predicted Environmental Concentration) of a given substance and the concentrations below which no changes in the environment are observed (PNEC - Predicted No Effect Concentration), or to determine the maximum levels of exposure to the substance (DNEL - Derived No Effect Level) [63]. DNEL value is extrapolated from the experimental data collected on tested organisms with the highest concentration of the substance, at which no harmful effects are observed (NOAEL No Observed Adverse Effect Level), and takes into account interspecies and intraspecies differences, and the differences in the duration of exposure. Assessment factors are assigned to individual parameters ( $A F-$ Assessment factor). The AF values are divisors of the NOAEL values into DNEL. The determination of DNEL based on the NOAEL is described in more detail, i.e. in work [64].

\section{Soil}

This stage focuses on estimating soil concentrations after the long-term use of the sewage sludges. It should include all processes affecting the fate of soil pollutants, including [59]:

- application of sewage sludges as the main source of pollutants,

- biodegradation,

- migration of pollutants to water,

- uptake of pollutants by plants,

- plant harvest.

The calculation should take into account the average concentration of pollutants, as continuous application of the most polluted sludges in the same place is unlikely to happen. The pollutants concentrations in soil are estimated referring to three different time periods: immediately after the introduction of the sewage sludge, 90 days after application, and after 100 years. Determination of concentration of the substance just after the application is used to assess the risk of non-accumulative substances. After 90 days, they correspond to the average concentration during the growing season of 180 days. Predicting concentrations after 100 years from the application of sludge is used to model the process of accumulating the substances [58, 59].

The concentration of pollutants in the soil due to a single application of the municipal sewage sludges for use in agriculture can be calculated according to Equation 1 [59]:

$$
\mathrm{C}_{\text {conso }}=\frac{\mathrm{C}_{\mathrm{sl}} \cdot \mathrm{APPL}_{\mathrm{sl}} \cdot 10}{\mathrm{DEPTH}_{\mathrm{so}} \cdot \mathrm{RHO}_{\mathrm{so}}}
$$


$\mathrm{C}_{\text {conso }}$ - concentration of pollutant in soil after one application of sewage sludge [mg $\times \mathrm{kg}^{-1}$ ]

$\mathrm{C}_{\mathrm{sl}}-$ concentration of pollutant in dry sewage sludge [mg $\left.\times \mathrm{kg}^{-1}\right]$

$\mathrm{APPL}_{\mathrm{Sl}}-$ dry sludge application rate $\left[\mathrm{t} \times \mathrm{ha}^{-1}\right]$; (rate of sludge application: agriculture: 40 or $60\left[\mathrm{t} \times \mathrm{ha}^{-1} \times 10\right.$ $\left.\mathrm{yrs}^{-1}\right]$ )

DEPTH $_{\text {so }}$-mixing depth of soil [m]; (mixing zone in green area/ploughing layer agriculture $=0.1 / 0.2[\mathrm{~m}]$ )

$\mathrm{RHO}_{\text {so }}$ - bulk density of soil $\left[\mathrm{kg} \times \mathrm{m}^{-3}\right]$; (dry/wet soil $=$ $1200 /$ wet soil $\left.=1400\left[\mathrm{~kg} \times \mathrm{m}^{-3}\right]\right)$

Equations 2 and 3 can be used when the sewage sludge is used to fertilize park greenery [59]. In the green areas, a $5 \mathrm{~cm}$ layer of sewage sludge is mixed with a $10 \mathrm{~cm}$ layer of soil (33\% of sewage sludges by volume), and $30 \%$ sewage sludges (by volume) are mixed with $70 \%$ of soil in the soil mixtures.

$$
\begin{gathered}
\mathrm{C}_{\mathrm{pa}}=\frac{0.67 \cdot \mathrm{C}_{\mathrm{so}}(0) \cdot \mathrm{RHO}_{\mathrm{so}}+0.33 \cdot \mathrm{C}_{\mathrm{sl}}(0) \cdot \mathrm{RHO}_{\mathrm{sl}}}{0.67 \cdot \mathrm{RHO}_{\mathrm{so}}+0.33 \cdot \mathrm{RHO}_{\mathrm{sl}}} \\
\mathrm{C}_{\text {som }}=\frac{0.7 \cdot \mathrm{C}_{\mathrm{so}}(0) \cdot \mathrm{RHO}_{\mathrm{so}}+0.3 \cdot \mathrm{C}_{\mathrm{sl}}(0) \cdot \mathrm{RHO}_{\mathrm{sl}}}{0.7 \cdot \mathrm{RHO}_{\mathrm{so}}+0.3 \cdot \mathrm{RHO}_{\mathrm{sl}}}
\end{gathered}
$$

$\mathrm{C}_{\mathrm{pa} \text {, som }}$ - concentration of pollutant in park soil or soil mixture $\left[\mathrm{mg} \times \mathrm{kg}^{-1}\right]$

$\mathrm{C}_{\mathrm{so}(0)}$ - concentration of pollutant in soil used in soil mixture $\left[\mathrm{mg} \times \mathrm{kg}^{-1}\right]$

$\mathrm{C}_{\mathrm{sl}(0)}$ - concentration of pollutant in sewage sludge used in soil mixture $\left[\mathrm{mg} \times \mathrm{kg}^{-1}\right.$ ]

$\mathrm{RHO}_{\text {so }}$ - bulk density of dry soil $\left[\mathrm{kg} \times \mathrm{m}^{-3}\right]$

$\mathrm{RHO}_{\mathrm{sl}}$ - bulk density of dry sewage sludge $\left[\mathrm{kg} \times \mathrm{m}^{-3}\right]$

The concentration of pollutants measured in the agricultural soils results from the background concentration, i.e. the concentration that is caused by substances occurrence in the bedrock and natural sources, such as forest fires, volcanoes, etc., and the sources caused by anthropogenic effects (the use of mineral fertilizers, liming and pesticides, as well as the atmospheric deposition). The local predicted concentration on a tested soil can be calculated according to equation 4 [59]:

$$
\mathrm{PEC}_{\text {Local }}=\mathrm{PEC}_{\mathrm{RNS}}+\mathrm{C}_{\mathrm{OSS}}+\mathrm{C}_{\mathrm{Sl}}
$$

$\mathrm{PEC}_{\text {Local }}$ - predicted environmental concentration (PEC) in local soil

$\mathrm{PEC}_{\mathrm{RNS}}$ - PEC of regional natural soil

$\mathrm{C}_{\mathrm{OSS}}$ - concentration of pollutant from other sources of soil $\left[\mathrm{mg} \cdot \mathrm{kg}^{-1} \mathrm{dw}\right]$

$\mathrm{C}_{\mathrm{S} 1}$ - concentration of pollutant in soil after one application of sewage sludge $\left[\mathrm{mg} \cdot \mathrm{kg}^{-1} \mathrm{dw}\right]$

\section{Plants}

Roots are the most important way of collecting pollutants by plants from the soil. The transfer of pollutants from the soil to the root zone (rhizosphere) is done mainly by regular water uptake by plants. This type of absorption of pollutants should be taken into account at the stage of predicting their concentrations in plants. It is assumed that the absorption of compounds from other sources (e.g. absorption of volatile compounds) is of negligible importance [59]. The absorption of pollutants by plants depends on contaminants bioavailability, and the differences in collection is due to the differences in species, physicochemical parameters of the soil (soil reaction, clay, and content of organic matter), and the characteristics of the pollutants. The concentration of pollutants in grains, stalks, and leaves, as well as the bioconcentration factor $(\mathrm{BCF})$ for a given part of a plant is taken into account (Equation 5) when calculating the predicted concentrations of inorganic pollutants in soil. The BCF value varies depending on the type of pollutant and a part of the plant. Regardless of the part of the plant, zinc has the highest BCF value. For example, for leafy vegetables, the $\mathrm{BCF}$ value for zinc is $\mathrm{BCF}=0.30$ compared to $\mathrm{BCF}=0.003$ for chromium.

$$
\mathrm{C}_{\mathrm{pl}}=\mathrm{C}_{\mathrm{so}} \cdot \mathrm{BCF}
$$

$\mathrm{C}_{\mathrm{pl}}-$ concentration of pollutant in grain, stem, leaf $\left[\mathrm{mg} \cdot \mathrm{kg}^{-1} \mathrm{dw}\right]$

$\mathrm{C}_{\mathrm{so}}$ - total concentration in soil $\left[\mathrm{mg} \cdot \mathrm{kg}^{-1} \mathrm{dw}\right]$

$\mathrm{BCF}$ - bioconcentration factor for the actual part of plant [dw plant/dw soil]

Calculating the predicted organic pollutant concentrations is more complicated. The models used for this purpose differ from each other in their complexity, structure and input data. They can be the simple linear equations based on the BCF values of a single substance, and these based on complex parameters and intervals taking into account several elements of the plant (root, stem, leaves, etc.), by means of which plant collects substances from various elements of the environment (e.g. soil and air) [6569]. The calculations consider the number of sewage sludges used per year and the duration of application (90 days after the first application or 100 years after the first application with a time step of 10 years for each subsequent application). Within 90 days, the impact of non-accumulating compounds is estimated, in 100 years - of the cumulating compounds.

\section{Water}

Transport of pollutants from the soil to surface waters takes place through the drainage systems or surface runoff. The number of pollutants leached into the surface waters depends on the type of soil, meteorological conditions and the physical or chemical properties of the pollutants. It is assumed that the predicted concentration of pollutants in the surface waters is the sum of the concentrations of pollutants discharged by the drainage systems and as a result of the surface runoff. When determining the predicted concentrations in the surface waters, the dilution factor 
for the substance is assumed as 100, in the case of drainage waters (drainage systems) and waters coming from the surface runoff the dilution factor is 10 . These values should be adjusted depending on the location of these water sources. The higher factor is assumed for waters distant from the areas of fertilizer application, lower for waters more exposed to pollutants. Modelling and forecasting of pollutants in waters are carried out using the simulation programs, e.g. MACRO 5.0 $[70,71]$.

The predicted concentration of pharmaceutical substances coming from the point sources, e.g. as a result of pollutants emissions, together with the discharge of wastewater from the wastewater treatment plants, can be estimated using equation 6 [72]. The calculated results represent the predicted concentration at some distance from the source on the day of discharge. On a local scale, it is assumed that the wastewater passes through the wastewater treatment plants before entering the environment, and in the standard environment: $70 \%$ of the wastewater after the biological treatment plant, $30 \%$ directly to the surface waters. Therefore it is assumed that there is no biodegradation or retention of pharmaceuticals in the wastewater treatment plant.

$$
\mathrm{PEC}_{\mathrm{ww}}=\frac{\mathrm{DOSE} \cdot \mathrm{F}}{\mathrm{V} \cdot \mathrm{D}}
$$

$\mathrm{PEC}_{\mathrm{ww}}$ - predicted environmental concentration for surface waters originating from the discharged wastewater $\left[\mathrm{mg} \cdot \mathrm{dm}^{-3}\right] ; \mathrm{PEC}_{\mathrm{ww}}<0.01 \mu \mathrm{g} \cdot \mathrm{dm}^{-3}$ - no further actions required, $\mathrm{PEC}_{\mathrm{ww}}>0.01 \mu \mathrm{g} \cdot \mathrm{dm}^{-3}$ - further actions required (analysis of the environmental effect)

DOSE - maximum daily intake of the drug by one inhabitant $\left[\mathrm{mg} \cdot \mathrm{M}^{-1} \cdot \mathrm{d}^{-1}\right]$

$\mathrm{F}$ - the percentage of the population treated with the drug [-]; default value $\mathrm{F}=0.01$

$\mathrm{V}$ - the volume of wastewater per inhabitant per day $\left[\mathrm{dm}^{3} \cdot \mathrm{M}^{-1} \cdot \mathrm{d}^{-1}\right]$; depending on the region and habits D - Dilution factor of surface waters [-]; default value $=10$

\section{Animals}

Animals may be exposed to the contaminants presented in the sewage sludges through grazing and consumption of fodder from plants grown in the areas fertilized with the sewage sludges. The animals can accumulate pollutants due to the consumption of polluted water. The exposure of animals to pollutants depends on the type of food consumed and the place of grazing. Depending on the quality of the grassland and mineral needs, the animals can also accumulate pollutants along with the soil they eat.

\section{Risk Characteristics}

After assessment of the exposure routes and of the dose (concentration) - response (effect) dependence, for all elements of the environment, the quantitative or qualitative risk characterization is performed [72].

The quantitative risk characterization is performed by comparing the PEC with the PNEC. This stage is carried out separately for each of the elements of the environment presented in section 5.3. The quantitative $\mathrm{PEC} / \mathrm{PNEC}$ estimation for assessing the environmental risk of a substance is made by comparison of the concentration PEC with the concentration, below which the unacceptable effects on organisms (PNEC) will not occur. The PNEC value is calculated by entering an appropriate estimation factor such as, for example, $\mathrm{LC}_{50}$ or NOEC. If the value of the PEC/PNEC ratio is less than, or equal to unity, the data used should be verified and further tests carried out, as well as the risk control management should be taken. If the PEC/PNEC ratio is greater than one, no further actions are needed. The qualitative ecological risk assessment is carried out for these cases where the quantitative assessment of exposure and/or effects is not possible $[63,73]$.

The risk characterization stage should be carried out in accordance with the following stages [74]:

- determination of the PEC/PNEC factors for different considered elements of the environment,

- depending on the PEC/PNEC factors:

- determine, whether further testing may lead to a change in these factors,

- $\quad$ if necessary - additional information shall be requested,

- the PEC/PNEC ratio needs to be improved.

This process should be continued until the final conclusion on the environmental risks can be reached.

\section{Conclusions}

Due to the rapid depletion of phosphorus resources [75], it is assumed to use the stabilized municipal sewage sludges as a substrate for the production of organic and mineral fertilizers. However, there is a risk that municipal-sewage-sludge based fertilizers may cause a potential sanitary and epidemiological threat due to the different chemical and biological composition. Based on the literature review, it was found that the safety analysis and environmental risk assessment of municipal-sewage sludge-based fertilizers should also take into account parameters (physical and biological) which have not been included in legal regulations. Due to the potential health risk that sewage sludgebased fertilizers may cause, a comprehensive study in various type of the environment (leachate, ground and surface waters, soil and plants) is justified. Among the most commonly safety analysis methods of fertilizers are risk assessment. Based on the risk analysis, the environmental risk of fertilizer products is estimated at local or regional scales. Additional concerns are caused by the presence of micropollutants in the sewage sludge, including pharmaceutical substances such as 
17- $\alpha$-ethinylestradiol, $17-\beta$-estradiol, estrone, diclofenac, and ibuprofen. These pollutants are usually present in low concentrations, but long exposure period makes their monitoring as important as the basic parameters. For many micropollutants that may appear in the sewage sludge composition, the predicted concentration in the environment have not been determined and no risk assessment has been carried out. Therefore a multi-approach is necessary. The safety assessment of fertilizers based on the municipal sewage sludge should be carried out at every stage of the process that affects the safety of individual elements of the ecosystem. The multi-approach contributes to improve the technology of sewage sludge treatment and improve the technology of fertilizers production, and thus prevents entering contaminants to product. In this way, it will allow us to identify shortcomings at the sludge treatment processing stage and to propose implementable solutions reducing the risk of the use of fertilizers.

\section{Conflict of Interest}

The authors declare no conflict of interest.

\section{References}

1. Polish regulation: The Ordinance of the Minister of Agriculture and Rural Development of 18 June 2008 on implementation of certain provisions of the Act on fertilisers and fertilizing (Journal of Laws 2008 No. 119 item. 765) [In Polish].

2. MARTIN J., CAMACHO-MUNOZ D., SANTOS J.L., APARICIO I., ALOSNO E. Occurrence of pharmaceutical compounds in wastewater and sludge from wastewater treatment plants: Removal and ecotoxicological impact of wastewater discharges and sludge disposal. Journal of Hazardous Materials, 239-240, 40, 2012.

3. APARICIO I., MARTIN J., SANTOS J.L., ALONSO E. Determination of pharmaceutical compounds in sewage sludge from municipal wastewater treatment plants. In: Life cycle assessment of wastewater treatment, Naushad Mu. (Eds), CRC Press, Taylor \& Francis Group, Broken Sound Parkway NW, 2018.

4. IVANOVÁ L., MACKULAK T., GRABIC R., GOLOVKO O., KOBA O., STAŇOVÁ A.V., SZABOVÁ P., GRENČÍKOVÁ A., BODÍK I. Pharmaceuticals and illicit drugs - A new threat to the application of sewage sludge in agriculture. Science of The Total Environment, 634, 606, 2018.

5. Directive 2000/60/EC of the European Parliament and of the Council of 23 October $\mathbf{2 0 0 0}$ establishing a framework for Community action in the field of water policy.

6. Commission Implementing Decision (EU) 2018/840 of 5 June 2018 establishing a watch list of substances for Unionwide monitoring in the field of water policy pursuant to Directive 2008/105/EC of the European Parliament and of the Council and repealing Commission Implementing Decision (EU) 2015/495 (notified under document C(2018) 3362).
7. Polish regulation: The Act of 14 December 2012 on waste (Journal of Laws 2019 item. 701) [In Polish].

8. Polish regulation: Regulation of the Minister of the Environment of 6 February 2015 on municipal sewage sludge (Journal of Laws 2015 item. 257) [In Polish].

9. ZDYBEL J., KARAMON J., DĄBROWSKA J., RÓŻYCKI M., BILSKA-ZAJĄC E., KŁAPEĆ T., CENCEK T. Parasitocological contamination with eggs Ascaris spp., Trichuris spp. And Toxocara spp. of dehydrated municipal sewage sludges in Poland. Environmental Pollution, 248, 621, 2019.

10. ARANOWSKI R., LEWANDOWSKI W.M. Environmental protection technologies in industry and energy, Polish Scientific Publishers PWN, Warszawa, 2016 [In Polish]

11. LATOSIŃSKA J. The analysis of heavy metals mobility from sewage sludge from wastewater treatment plants in Olsztyn and Sitkówka-Nowiny. The Engineering and Protection of Environment, 17 (2), 243, 2014 [In Polish, English summary].

12. ROSIK-DULEWSKA CZ., GLOWALA K., KARWACZYŃSKA U. Production of granules from municipal sewage sludge and fly ash for their natural (fertilizer) recovery. Monograph, Institute of Envorinmental Engineering, Polish Academy of Sciences in Zabrze, 2016 [In Polish].

13. Polish Regulation: The Act of $20^{\text {th }}$ July 2017 on Water Law (Journal of Laws 2018 item. 2268) [In Polish].

14. Directive 2013/39/EU of the European Parliament and of the Council of 12 August 2013 amending Directives $2000 / 60 / \mathrm{EC}$ and $2008 / 105 / \mathrm{EC}$ as regards priority substances in the field of water policy Text with EEA relevance.

15. SMUDA K., DUDZIAK M. Changes of the EU and polish legislation concerning pollution in the aquatic environment in 2010-2016. Architecture: Civil Engineering Environment, 3, pp. 141-146, 2016.

16. WŁODARCZYK-MAKUŁA M. The Selected Organic Micropollutants in Water and Soils. Monograph. Częstochowa University of Technology Publisher, Częstochowa, 2013 [In Polish].

17. KOZAK J., WŁODARCZYK-MAKUŁA M. General characteristics of biological quality control methods. LAB Laboratoria, Aparatura, Badania, 21 (6), 22, 2016 [In Polish].

18. PELTOLA THIES J., LANTTO T.A., LAPENNA S., MULLER G., KLOSLOVA Z., CALEY J., ANDERSEN S., GUDBRANDSEN M., HOFER T., MYHRE O., VERVRUGGEN E., LEPPER P. Use of toxicokinetic data in bioaccumulation assessment. Toxicology Letters, 258, S226, 2016.

19. ZGÓRSKA A., BONDARUK J., DUDZIAK M. Impact of industrial discharges on aquatic ecosystems of Kłodnica river based on the results of bioassays battery. Ecological Engineering, 20 (2), 15, 2019 [In Polish].

20. EPA 600/4-90-027F, Methods for Measuring the Acute Toxicity of Effluents and Receiving Waters to Freshwater and Marine Organisms, 1993.

21. NEALE P.A., ESCHER B.I. In vitro bioassays to assess drinking water quality. Current Opinion in Environmental Science \& Health, 7, 7, 2019.

22. EPA 600/4-91-003, Short-Term Methods for Estimating the Chronic Toxicity of Efflents and Receiving Water to Marine and Estuarine Organisms, 2002.

23. NIWA MfE80205, Standard Methods for Whole Effluent Toxicity Testing: Development and Application, 1998. 
24. ISO 11348-1:2007, Determination of the inhibitory effect of water samples on the light emission of Vibrio fischeri (Luminescent bacteria test), 2007.

25. ASTM E1218-97a. Standard Guide for Conducting Static 96-h Toxicity Tests with Microalgae, 1997.

26. ALVES P.R.L., CARDOSO E.J.B.N. Overview of the standard methods for soil ecotoxicology testing, in: Invertebrates - Experimental Models in Toxicity Screening Eds. Larramendy M. L. and Soloneski S., IntechOpen, 2016.

27. ISO 17155:2012, Soil quality - Determination of abundance and activity of soil microflora using respiration curves, 2012.

28. ISO 18400-206:2018, Soil quality - Sampling - Part 6: Guidance on the collection, handling and storage of soil for the assessment of aerobic microbial processes in the laboratory, 2018.

29. PN-EN ISO 14238:2014-04, Soil quality - Biological methods- Determination of nitrogen mineralization and nitrification in soils and the influence of chemicals on these processes, 2014.

30. OECD, Test No. 216: Soil Microorganisms: Nitrogen Transformation Test, OECD Guidelines for the Testing of Chemicals, Section 2, OECD Publishing, Paris, 2000.

31. ISO 15685:2012, Soil quality - Determination of potential nitrification and inhibition of nitrification - Rapid test by ammonium oxidation, 2012.

32. OECD, Test No. 217: Soil Microorganisms: Carbon Transformation Test, OECD Guidelines for the Testing of Chemicals, Section 2, OECD Publishing, Paris, 2000.

33. PN-EN ISO 14240-1:2011, Soil quality - determination of soil microbial biomass - part 1: substrate-induced respiration method, 2011.

34. PN-EN ISO 14240-2:2011, Soil quality - Determination of soil microbial biomass - Part 2: Fumigation-extraction method, 2011.

35. ISO 23753-1:2019, Soil quality - Determination of dehydrogenases activity in soils - Part 1: Method using triphenyltetrazolium chloride (TTC), 2019.

36. ISO 23753-2:2019-07, Soil quality - Determination of dehydrogenases activity in soils - Part 2: Method using iodotetrazolium chloride (INT), 2019.

37. BEYER J., PETERSON K., SONG Y., RUUS A., GRUNG M., BAKKE T., TOLLEFSEN K.E. Environmental risk assessment of combined effects in aquatic ecotoxicology: A discussion paper. Marine Environmental Research, 96, 81, 2014.

38. JAKUBUS M.B., TATUŚKO N. Review of selected biological methods of assessing the quality of natural environment. Ecological Engineering, 42, 78, 2015 [In Polish, English summary].

39. OECD, Test No. 207: Earthworm, Acute Toxicity Tests, OECD Guidelines for the Testing of Chemicals, Section 2, OECD Publishing, Paris, 1984.

40. ISO 11268-1:2012, Soil quality - Effects of pollutants on earthworms - Part 1: Determination of acute toxicity to Eisenia fetida/Eisenia Andrei, 2012.

41. ASTM E1676-97, Standard Guide for Conducting Laboratory Soil Toxicity or Bioaccumulation Tests With the Lumbricid Earthworm Eisenia fetida, 1997.

42. ASTM E2172-01, Standard Guide for Conducting Laboratory Soil Toxicity Tests with the Nematode Caenorhabditis elegans, 2014.

43. OECD, Test No. 232: Collembolan Reproduction Test in Soil, OECD Guidelines for the Testing of Chemicals, OECD Publishing, Paris, 2016.
44. OECD, Test No. 226: Predatory mite (Hypoaspis (Geolaelaps) aculeifer) reproduction test in soil, OECD Publishing, Paris, 2016.

45. PN-Z-19000-1:2001, Polish Standards, Soil quality assessment of the soil sanitary conditions - detection of the salmonella genus bacteria, 2001 [In Polish].

46. PN-Z-19000-4:2001, Polish Standards, Soil quality assessment of the soil sanitary conditions - Detection of eggs of the intestinal parasites Ascaris lumbricoides and Trichuris trichiura, 2001 [In Polish].

47. VENKATESAN A.K., HALDEN R.U. Wastewater treatment plants as chemical observatories to forecast ecological and human health risks of manmade chemicals. Scientific Reports, 4, 3731, 2015.

48. BŁASZCZYK K., KRZYŚKO-ŁUPICKA T. Overview of the Research Methods for Sewage Sludge Used in Poland. Engineering and Protection of Environment, 17, 1, 117, 2014 [In Polish].

49. OECD, Test No. 208: Terrestrial Plant Test: Seedling Emergence and Seedling Growth Test, OECD Guidelines for the Testing of Chemicals, Section 2, OECD Publishing, Paris, 2006.

50. PN-ISO 11269-1: 2012, Soil quality - Determination of the effects of pollutants on soil flora - Part 1: Method for the measurement of inhibition of root growth.

51. ISO 11269-2:2012, Soil quality - Determination of the effects of pollutants on soil flora - Part 2: Effects of contaminated soil on the emergence and early growth of higher plants.

52. VAN DER VLIET L., VELICOGNA J., PRINCZ J., SCROGGINS R. Phytotoxkit: a critical look at a rapid assessment tool. Environ. Toxicol. Chem. 31 (2), 316, 2012.

53. RASTETTER N., GERHARD T. Toxic potential of different types of sewawge sludge as fertiliser in agriculture: ecotoxicological effects on aquatic, sediment and soil indicator species. Journal of Soils and Sediments, 17, 106, 2017.

54. TANNEBERGER K., KNOBEL M., BUSSER F.J.M., SINNIGE T.L., HERMENS J.L.M., SCHIRMER K. Predicting fish acute toxicity using a fish gill cell linebased toxicity assay, 47, 2, 1110, 2013.

55. KLAASSEN C.D., WATKINS III J.B. Basics of toxicology. MedPharm Polska, Wrocław, 2014 [In Polish].

56. PLAHUTA M., TIŠLER T., TOMAN M.J., PINTAR A. Efficiency of advanced oxidation processes in lowering bisphenol A toxicity and oestrogenic activity in aqueous samples. Archives of Industrial Hygiene and Toxicology, 65 (1), 77, 2014.

57. EPA, U.S. Environmental Protection Agency Office of Wastewater Management Washington, A Guide to the Biosolids Risk Assessments for the EPA Part 503 Rule, 1995.

58. DÉLÉRY L., GAY G., DENYS S., BRUNET H., DÉPORTES I. Health risk assessment for sewage sludge applied to land in France. Waste Management and the Environment III, 92, 537, 2006.

59. Risk assessment of contaminants in sewage sludge applied on norwegian soils. Opinion from the Panel on Contaminants in the Norwegian Scientific Committee for Food Safety, Oslo, 2009.

60. OLARINMOYE O., BAKARE A., UGWUMBA O., HEIN A. Quantification of pharmaceutical residues in wastewater impacted surface waters and sewage sludge from Lagos, Nigeria. Journal of Environmental Chemistry and Ecotoxicology, 8, 3, 14, 2016. 
61. IMAMURA F., MICHA R., KHATIBZADEH S., FAHIMI S., SHI P., POWLES J., MOZAFFARIAN D. Dietary quality among men and women in 187 countries in 1990 and 2010: a systematic assessment. Lancet Global Health, 3, 3, 132, 2015.

62. MOYA J., PHILLIPS L. A review of soil and dust ingestion studies for children. Journal of Exposure Science \& Environmental Epidemiology, 24, 545, 2014.

63. Regulation (EC) No 1907/2006 of the European Parliament and of the Council of 18 December 2006 concerning the Registration, Evaluation, Authorisation and Restriction of Chemicals (REACH), establishing a European Chemicals Agency, amending Directive 1999/45/EC and repealing Council Regulation (EEC) No 793/93 and Commission Regulation (EC) No 1488/94 as well as Council Directive 76/769/EEC and Commission Directives 91/155/EEC, 93/67/EEC, 93/105/EC and 2000/21/EC (Text with EEA relevance).

64. How to derive derived no-effect level (DNEL). Available online: https://www.chemsafetypro.com/Topics/CRA/ How_to_Derive_Derived_No-Effect_Level_(DNEL).html (accessed on 8 March 2020).

65. FANTKE P., WIELAND, WANNAZ C., FRIEDRICH R., JOLLIET O. Dynamics of pesticide uptake into plants: from system functioning to parsimonious modeling. Environmental Modelling \& Software, 40, 316, 2013.

66. ZHANG C., FENG Y., LIU Y.-W., CHANG H.-Q., LI Z.-J., XUE J.-M. Uptake and translocation of organic pollutants in plants: a review. Journal of Integrative Agriculture, 16, 0, 60345-7, 2006.

67. WU X., DODGEN L.K., CONKLE J.L., GAN J. Plant uptake of pharmaceutical and personal care products from recycled water and biodolids: a review. Science of The Total Environment, 536, 655, 2015.

68. TRAPP S. Calibration of plant uptake model with plantand site- specific data for uptake of chlorinated organic compounds into radish. Environmental Science \& Technology, 49, 1, 395, 2014.

69. TERZAGHI E., ZACCHELLO G., SCACCHI M., RASPA G., JONES K.C., CERABOLINI B., GUARDO A.D. Towards more ecologically realistic scenarios of plant uptake modelling for chemicals: PAHs in a small forest. Science of The Total Environment, 505, 329, 2015.

70. MACRO. Available online: https://esdac.jrc.ec.europa.eu/ projects/macro-0, (accessed on 8 March 2020).

71. VASCONCELOS F.C.W., CARVALHO S.A., SILVA S.H.G., SILVA E.A., GUERREIRO M.C., CURI N. Macro simulator (Version 5.0) for predicting atrazine herbicide behaviour in Brazilian latosols. Ciencia e Agrotecnologia, 37, 3, 211, 2013.

72. Technical guidance document on risk assessment. Part II. Institute for health and consumer protection. European chemicals bureau, European Communities, 2003.

73. Polish Regulation: The Act of 25 February 2011 on the chemical sub-stances and their mixtures (Journal of Laws 2019 item. 1225) [In Polish].

74. Guideline on the environmental risk assessment of 5 medicinal products for human use, EMEA/CHMP/ SWP/4447/00 Rev. 1, European Medicines Agency, 15 November 2018.

75. SATTARI S.Z., BOUWMAN A.F., GILLER K.E., VAN ITTERSUM M.K. Residual soil phosphorus as the missing piece in the global phosphorus crisis puzzle. Proceedings of the National Academy of Sciences, 109 (16), 6348, 2012. 